University at Buffalo School of Law

Digital Commons @ University at Buffalo School of Law

Fall 2002

\title{
Just Like Home: 'Home Cooking' and the Domestication of the American Restaurant
}

\author{
Samantha Barbas \\ University at Buffalo School of Law
}

Follow this and additional works at: https://digitalcommons.law.buffalo.edu/journal_articles

Part of the Food Studies Commons, and the United States History Commons

\section{Recommended Citation \\ Samantha Barbas, Just Like Home: 'Home Cooking' and the Domestication of the American Restaurant, Gastronomica, Fall 2002, at 43.}

Published as Samantha Barbas, Just Like Home: 'Home Cooking' and the Domestication of the American Restaurant, Gastronomica, v. 2, n. 4, at 23 (Fall 2002) . ( 2002 by the Regents of the University of California. Copying and permissions notice: Authorizati

C. IN COPYRIGHT

This Article is brought to you for free and open access by the Faculty Scholarship at Digital Commons @ University at Buffalo School of Law. It has been accepted for inclusion in Journal Articles by an authorized administrator of Digital Commons @ University at Buffalo School of Law. For more information, please contact lawscholar@buffalo.edu. 


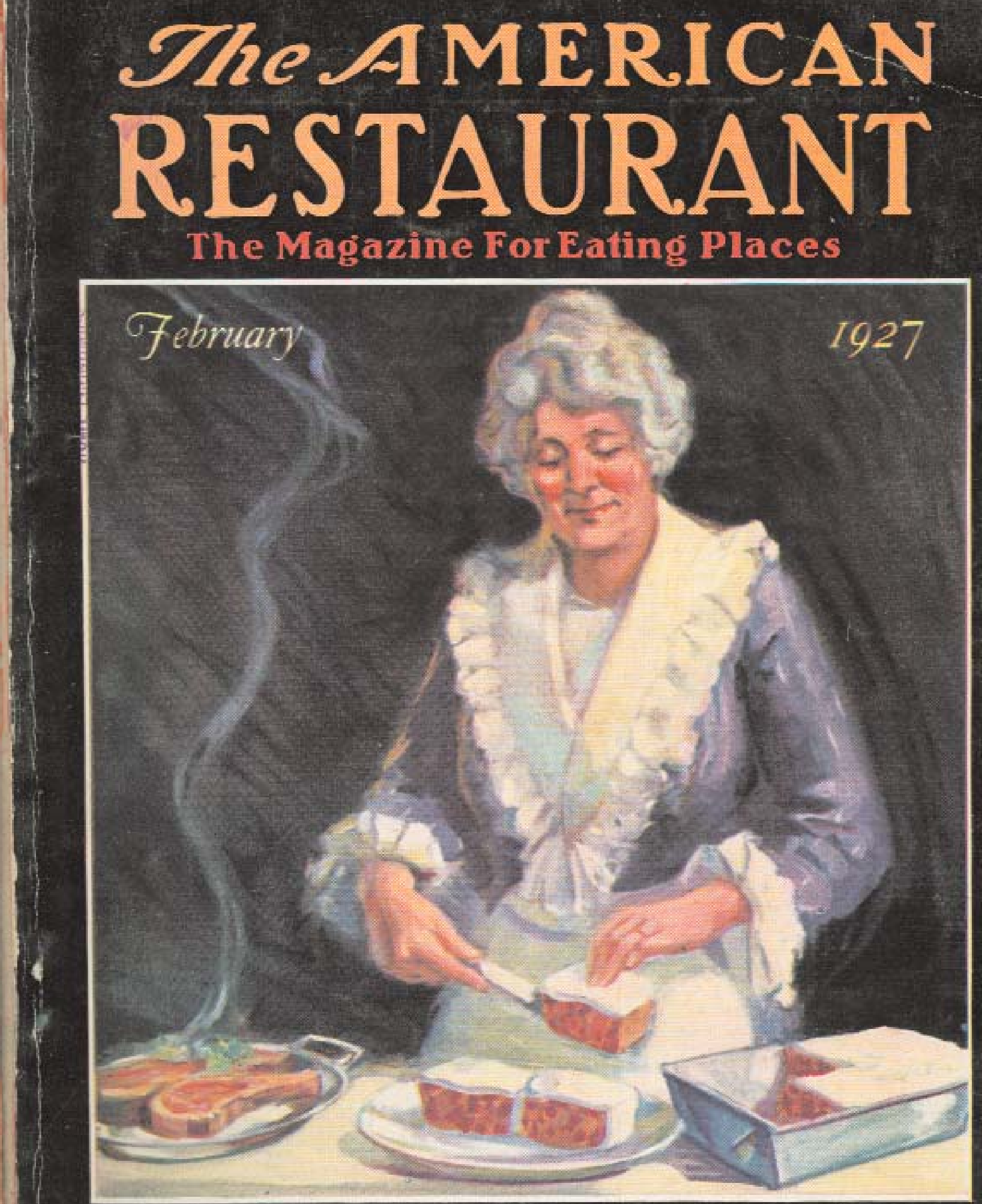

Practical Restaurant $\mathcal{O}$ peration - Storing The Trend in Sandwich Shops 


\section{Just Like Home \\ "Home Cooking" and the Domestication of the American Restaurant}

The 1920S MARKED THE END of an era. Gone were slowcooked dinners, cookies baked from scratch, and homemade bread. The days of old-fashioned home cooking, critics lamented, had long since disappeared. As the home economist Christine Frederick reported in 1927: "Woman is no longer a cook - she has become a can opener."'

Critics claimed that the causes of the decline were easy to identify. Small kitchens in cramped urban apartments gave wives too little room to prepare complex meals. Canned, frozen, and precooked foods eliminated the need to make meals from scratch, and a trend toward lighter eating put an end to elaborate multi-course lunches and dinners. But most to blame for the dismal state of affairs were women, or so the critics contended. Preoccupied with activities outside the home-social and leisure activities, and, for many, paid employment-they had lost their interest in cooking. Once upon a time, claimed one nostalgic observer, mothers took pride in well-cooked dinners and perfect pies. But "mothers today, many of them, do not make pies. They aren't particularly interested in pies. Their time is taken up with other things - movies, bridge parties, automobile rides." The modern woman who could cook "was about as rare as corned beef and cabbage in a Paris restaurant."

What for many critics was cause for lamentation became for the American restaurant industry a precious opportunity, and "home cooking" became the order of the day. For decades, restaurants had been seen as "greasy spoons" catering to single male workers. The 1920s furor over "home cooking" offered restaurants an unparalleled chance to win a mixed-sex, middle-class clientele. In an industry-wide campaign that lasted throughout the decade, restaurants advertised themselves as "country kitchens" serving hearty, traditional, "home style" fare. As surrogate homes, they would restore to the middle class the old-fashioned domes-

Left: Cover from The American Restaurant: The Magazine for Eating Places, February 1927. ticity that urbanization, modernization, and culinary standardization had stolen away.

The "home cooking" campaign, as it came to be known, proved extraordinarily successful. Enticed by grey-haired, matronly servers, inventive slogans, and cozy Victorian or Colonial decor, millions of middle-class Americans, once wary of restaurants, gradually began to eat out. Though the "home cooking" campaign gave way to other industry initiatives in the 1930s, restaurants would continue to woo customers by promising to revive traditional middle-class domesticity. Throughout the twentieth century, in fact, Americans were lured into restaurants with promises of home.

\section{The Domestic Front}

In their celebrated 1925 study of "Middletown" (Muncie, Indiana), sociologists Robert and Helen Lynd reported that the role of cooking in middle-class homes had changed significantly. Once "one of a woman's chief glories," cooking had, for many, become little more than a tedious routine. In the 189os, housewives bought "big chunks of meat and cut them up and used them in various ways." The modern wife, by contrast, bought meats that could be easily and quickly cooked. In the 1890 s, women spent weeks each summer canning fruits and vegetables; in 1925, they selected cans from grocers' shelves. "The modern housewife," lamented the local butcher, "has lost the art of cooking."

Had the Lynds gone from Indiana to Boston, or to California, Georgia, or Maine, they would have heard similar laments. "Gone are the days of the big, old-fashioned home kitchen, and with it, much of the old-fashioned home cooking," wrote a contributing editor of The Ladies' Home Journal in 1926. "The housewife has turned her thoughts and energies to other channels."4 According to Collier's magazine, modern "flappers" focused their attention on careers, "clothes, clubs, and climate," not housework, children, cooking, or any other "home' stuff." The result was lunches of soggy sandwiches and canned soups-or worse yet, the dreaded 
"delicatessen dinner." Perhaps a half-proud, half-disgruntled husband from Detroit expressed the sentiment best: "My wife," he quipped, "is the best little can opener in the world."

Though movies, automobiles, careers, and nightclubs may have contributed to the retreat from the kitchen, the death of home cooking was not an exclusively twentieth-century phenomenon. Rather, it was the product of more than fifty years of social, technological, and demographic changes that had dramatically altered methods of food production and preparation, urban and suburban living arrangements, public views of diet and health, and the role of women. It was not simply that women woke up one morning and chose to play tennis (or go to work) rather than cook, or to serve their families peanut butter sandwiches and soup from a can instead of pot roast and potatoes. For years, inventors, food producers, journalists, and nutritionists had been making that decision for them.

The initial blow to home cooking came in the second half of the nineteenth century, when newly organized foodprocessing conglomerates introduced American housewives to premixed, condensed, bottled, canned, and precooked foods. In the 1870 s and 1880 s, improved methods of canning gave rise to the Campbell's, Franco-American, and Heinz empires, and by the 1880 s cookbooks began recommending can openers as "necessary kitchen equipment." Across the country, women were discouraged from canning and pickling their own vegetables or preparing soups from scratch, as factories increasingly did the work for them. In one of the most significant transformations in the history of American domestic life, the home had changed from a realm of production into a unit of consumption. ${ }^{7}$

If canned foods began to simplify American cooking, electric appliances, which appeared increasingly in middleclass homes in the 1910s and 1920s, accelerated the trend. Heavily advertised and promoted in women's magazines, the new blenders, ovens, mixers, refrigerators, and skillets fitted perfectly the demands of modern, urban life. Living in a small city apartment with a "kitchenette," the businessman's wife of the 1920s could, with an electric coffee pot, skillet, and toaster, prepare breakfast for her husband in fifteen minutes flat. A "servant shortage" in the first part of the century had drastically reduced the number of domestics in middle-class households; not only were electric appliances easier to obtain than servants, they were also undeniably more efficient and obedient. Unlike the typical maid, boasted Sunset magazine in 1927, the electric mixer "willingly and quickly beats eggs, and stirs up a delicate cake, and when this is finished it chops the ice for the freezer and freezes the ice cream." No housewife could afford to be without this superhuman "electric servant."

\section{Home Economics}

Concerned primarily with profit, food-processing companies and appliance manufacturers cared little about the effect of their products on home cooking. But for the home economics movement, the transformation of home cooking became an all-consuming goal. This nationwide coalition of nutritionists, cooks, and "domestic scientists," organized at the turn of the century, was convinced that American cooking was largely unhygienic, economically inefficient, and nutritionally unsound: "Ignorance," wrote Charlotte Perkins Gilman in 1903, "is an essential condition of home cooking." The home economists attempted to rationalize cooking so thoroughly that it resembled less an art than a regimented science. East Coast cooking schools promoted a battery of precise (if bland) recipes backed by the latest nutritional discoveries: each simple, inexpensive dish contained an adequate number of calories in an acceptable ratio of proteins, carbohydrates, and fats. Cooks were to follow the recipes precisely, using only level measurements; they were not to deviate from the instructions. "Mother's cooking, the old-fashioned country kitchen, the groaning board laden with mince pies-all these familiar symbols of well-being were to them the symbols of degeneracy, and the women confined to such a past were doomed," historian Laura Shapiro has written. Though they did not explicitly endorse "labor saving" cooking, the home economists' enthusiasm for canned foods and electric appliances (canned soups were more "hygienic" than those prepared at home, and electric ovens produced precise, unvarying results) encouraged the kind of simplified, unskilled cooking that increasingly appeared in American kitchens. ${ }^{10}$

Judging from the diverse accounts of sociologists, writers, magazine editors, and other contemporary observers, the outcry over the decline of home cooking in the 1920s was more than just a nostalgic lament. Many women were, in fact, replacing their time-consuming, from-scratch preparations with the labor-saving alternatives offered by processed, pre-made, and canned foods. According to Robert and Helen Lynd, few Middletown wives of 1890 purchased their bread, but by the 1920s, fifty-five to seventy percent of all bread consumed in Middletown had been produced by commercial bakers. ${ }^{11}$ National consumption of canned goods similarly increased. In 1909, women spent 162 million dollars on canned goods; by 1919 the figure had risen to 575 million and by 1929 , to 930 million. ${ }^{12}$ In 1925, Good Housekeeping magazine was inundated with letters from readers requesting recipes based on electric cooking methods and canned foods. ${ }^{13}$ The letter writers may have resembled the women described by Sinclair 


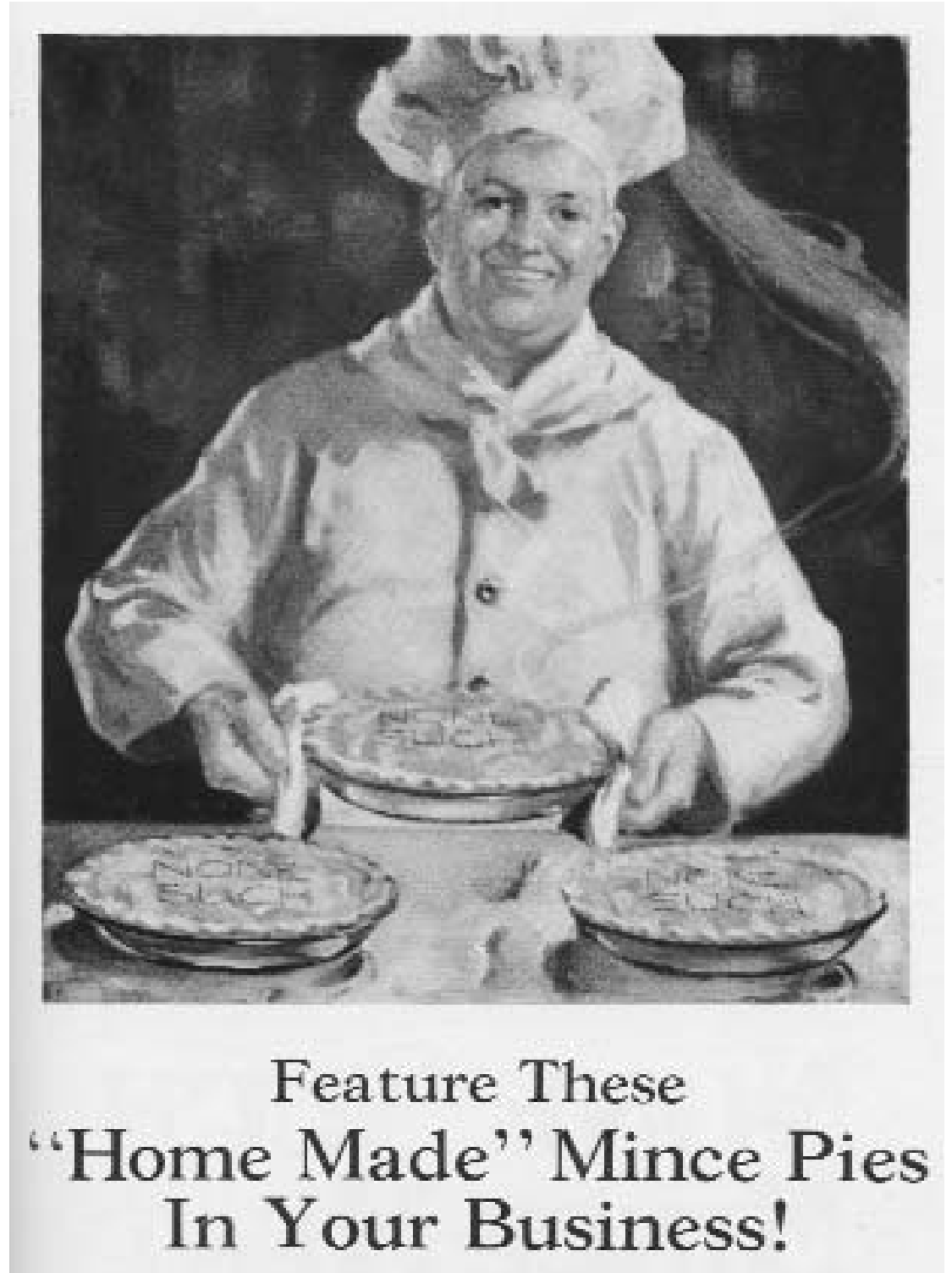

Sece Other Sude of This Page'
Advertisement for None Such Mince Pies. From The American Restaurant, November 1925, p.63.
Lewis in his 1922 novel, Babbitt-housewives who purchased most of their food from bakeries and delicatessens and served dinners of "burnt steak with canned peaches and store-bought cake." ${ }^{4}$ Popular cookbooks of the period, responding to the new cooking style, offered such recipes as Ginger Ale Salad (canned fruits congealed with ginger-ale-tinged Jell-O), Pineapple Fluff (canned pineapple served with marshmallows), or the latest in international cuisine, Italian Spaghetti (noodles covered with processed American cheese and canned tomato sauce). In the 1920s, a craze for “icebox cooking”dishes chilled in the refrigerator, rather than cooked-produced the ever-popular Monkey Pudding (vanilla pudding and 'Nilla wafers), frozen cream-cheese salad, Icebox Cake (ladyfingers layered in custard), and Tomato Frappe, chunks of frozen, condensed tomato soup served atop lettuce. ${ }^{15}$
Though obviously a product of industry, and unappetizing by today's standards, the new streamlined cooking seemed for millions of women in the 1910s and 1920s less a retreat into a kind of culinary barbarism than an important step forward. Recent breakthroughs in nutrition - in particular, the discovery of vitamins - supported the trend towards salads, sandwiches, and other light dishes, as did the new vogue for slimness. Perhaps most enticing about the new cuisine were its timesaving possibilities. Women's magazines of the 1920 reported that with electric appliances, canned and prepackaged foods, and agile kitchen maneuvers that eliminated "wasted motion," modern housewives could liberate themselves from unnecessary physical exertion and old-fashioned "kitchen slavery." "Here's a woman who can prepare, cook, and serve breakfast and dinner for two in 71 
minutes," boasted Collier's magazine in 1926. "She tells exactly how she does it, and how any woman can save time and energy...in the same way." 16

It is tempting to imagine this young wife rushing out of the kitchen to see a movie or spend a leisurely day on the town. In reality, however, women of the 1920s spent as much time doing housework as they had before. Housewives not only bore the burden of planning, budgeting, and shopping for "convenience" foods, but standards of cleanliness were higher, meals were expected to be more varied, and children were supposed to be raised under greater maternal supervision than in previous decades. Studies conducted by the United States Bureau of Home Economics indicate that between 1926 and 1929 women spent more time, not less, on household chores, even though they were increasingly taking advantage of canned goods and electric appliances. In 1926, housewives spent an average of fifty-one hours per week on domestic work, including twenty-three hours on food planning and preparation; by 1929, the time spent on housework had increased to fifty-three hours, twenty-six of which were devoted to meals. Time involved in family care, home care, and laundry similarly increased. ${ }^{17}$ The women who embarked on part-time or full-time paid employment during the 1910s and 1920s (by 1920 two million women, many of them married, worked in the burgeoning clerical field, in addition to millions in retail and industry) faced the even more formidable challenge of balancing their professional and domestic obligations. Meals "that cook while the table is being set and the salad arranged, that is what the busiest of housewives, the business women are demanding," The Ladies' Home Journal announced in 1926 in one of its many articles on "hurry-up dinners." ${ }^{18}$ As historian Jennifer Scanlon has noted, it was during this period that the term "superwoman" was coined to describe a woman who could juggle her overwhelming slate of commitments while concealing her exhaustion. ${ }^{19}$

To many social reformers and critics, however, it was women's laziness and selfishness, rather than industriousness, that gave rise to "can opener" cuisine. In the nineteenth century, wrote Christine Frederick, hard-working grandmothers cooked to pass the time, whereas modern women indulged in movies, radio programs, and other forms of commercial leisure - anything to avoid dreaded time in the kitchen. Didactic tales in The Ladies' Home Journal and other women's magazines warned wives against employment, feminism, or other "distractions" from their duties; women who purchased canned goods or take-out meals were accused of being "home wreckers," carelessly sowing the seeds of family conflict and marital strife. Far too many 
honeymoons, warned one observer, "end up with the husband in anger and the wife in tears over a poorly prepared dinner." ${ }^{20}$ Similarly, a "sporting" woman might seem attractive before marriage, but what comfort was a wife who played a "good game of tennis" if, as a consequence, she served "delicatessen dinners"? ${ }^{21}$

Like many social reformers of the period, the critics of modern cooking in the 1920 s held conflicting allegiances and impulses. Enthusiastic supporters of industry and technology, they championed processed foods, yet longed for the "pies mother used to make." They encouraged the use of labor-saving devices and praised the quest for household efficiency, yet criticized women who used canned goods for their apparent lack of interest in cooking. One writer yearned to be back in the time when mothers spent hours cooking roasts, thickening puddings, and kneading bread - when a mother baked "her temperament, her own loving care and kindness" right into her meals! Yet even this die-hard sentimentalist could not approve of the inconsistency of even the best old-fashioned "home cooking," which varied on "wash days and ironing days," when meals received less attention. ${ }^{22}$

Many critics, it seemed, envisioned a kind of domestic utopia in which women used the latest technological innovations yet lost none of their devotion to home and family. Of course, many women did precisely that-they spent longer hours on housework in spite of their blenders, can openers, and toasters. Those, however, who used laborsaving technology as a way to help balance job and home, or who preferred other activities to cooking, threatened critics who saw in the new culinary style nothing less than the demise of traditional womanhood. With one foot in the future and the other in the past, these critics dreamed of a modern, electric-powered "cult of domesticity," in which women used twentieth-century technology but retained a nineteenth-century frame of mind.

The outcry over the demise of "home cooking," then, was not only a reaction to the commercialization and standardization of American cuisine, but also a reflection of contemporary fears about changing gender roles. Afraid that the shift from apple pie to icebox cake signaled more than just a harmless culinary fad, critics bemoaned the death of traditional American cooking and the vision of domesticity that accompanied it. Homemade bread became the emblem of the stay-at-home mother; mincemeat pie the symbol of the docile, devoted wife. As they hurtled headlong into the future, Americans in the 1920 s clung desperately to nostalgic remnants of the past.

\section{The "Home Cooking" Campaign}

In 1924, the National Restaurant Association held its annual conference in Chicago. An event that promised to be "practical, profitable, and pleasing," according to industry journal National Restaurant News, the exhibition centered around an issue of vital interest to modern restaurateurs: the art of "commercializing home cooking" - preparing entrees, soups, breads, and desserts that tasted "just like home." 23

For an industry long associated with rowdy working-class customers, unpalatable meals, and near-certain indigestion, talk of "home baked" pies and "home cooked" dinners seemed distinctly out of character. Though opulent establishments like the famed Delmonico's in New York served wealthy patrons the latest haute cuisine, the word "restaurant" typically conjured images of inexpensive lunch counters and coffee shops catering to a predominantly male, workingclass clientele. Throughout the first two decades of the century, recalled one restaurateur, “'greasy spoon' was an all-too-common appellation for almost any restaurant."24 "A blue fog of mixed tobacco smoke and grease" hung ominously over the tables, and sawdust covered many a dining-room floor. ${ }^{25}$ Although by the late 1910 s many restaurants had upgraded their cuisine and decor and white-collar workers had begun venturing into urban cafeterias and lunchrooms for a quick meal, very few restaurants were deemed acceptable or appropriate for a middle-class, mixedsex clientele. To most Americans, eating in restaurants was a hurried, unappetizing, and generally unpleasant experience-nasty, brutish, and short.

For the National Restaurant Association - a coalition of restaurant owners, suppliers, and managers organized in 1919changing the rough, working-class image of the restaurant took on overtones of a moral crusade. Determined to win a respectable middle-class patronage, prominent restaurateurs urged their colleagues to revamp their menus and decor. "Efficiency in ventilation has... a very pleasing effect on women patrons, as well as carefully planned, soft lighting," advised one article in National Restaurant News. "Improper lighting creates a hard, cold repellent environment, and the waste light reflects and glares into eyes already wearied by a strain of work until the entire nervous system is jangled out of tune." 26 "Larger cash register totals... have been the lot of those who have given more than ordinary thought to...the cleanliness of their restaurants," counseled another. "It has been proven that guests will gravitate to the place that always looks clean." 27 Yet despite the innovations, public resistance to restaurants remained strong. People didn't eat out, observed one restaurant owner, "on their own free will," but visited restaurants only "when they have no place else 
to eat." 28 Americans, it seemed, were not simply wary of the restaurant's "greasy spoon" image, but were also averse to the very idea of eating away from their own kitchens. "Home," remarked a cafeteria owner, was his primary competitor - a formidable opponent, but one that seemed to be growing weaker. ${ }^{29}$

For the restaurant industry, the demise of home-cooked meals was a godsend, sparking visions of profit. If middleclass Americans, particularly husbands, were unhappy with their family meals; if they longed for "home style" breads and cakes and "old fashioned" roasts and stews, restaurants could serve these nostalgic foods as easily as ham and eggs. Most family dinners were "poorly prepared and cooked by an inexperienced wife," claimed the Schrafft's restaurant chain; in their place Schrafft's offered "old-style home cooking...the kind of food [patrons] ought to get in the home, but don't." 30 "Can wifey do better cooking, or better baking, or better salad making, than can be done in the new Boos cafeteria?" boasted a popular California restaurant. "Really, the chances are all against wifey." 31

Launched around the time of the 1924 convention, the "home cooking" campaign consumed the efforts of the restaurant industry. In the trade journals National Restaurant News and The American Restaurant, industry leaders reaffirmed the wisdom of their publicity scheme and exhorted colleagues to adopt "home cooking" in their lunchrooms, coffee shops, and cafeterias. "The cooking in every restaurant must surpass that in the average home," urged writer and self-appointed "home cooking" expert Mary Wilson. "The restaurant today needs...real home made food, cooked as well as 'mother' can cook it-yes, even better than mother can." ${ }^{32}$ A quiet, "homelike" atmosphere, industry leaders claimed, complemented the culinary nostalgia in important ways: a patron's first impression of a restaurant should make her think undeniably of home. "There must be refinement where refinement is required; cheeriness whenever it is desirable...plainness when needed; display or show wherever they, too, are needed, but all the time there must be hominess. Remember that word, "homey." "Home style" recipes, "home-baked" bread, "homey" atmosphere, "homemade" dinners "home," joked one restaurateur, had become the most "abused word in the entire restaurant language." 33

Yet after the initial flurry of optimism and ambition had passed, campaign promoters faced serious questions. What, exactly, did "home cooking" mean? Was it chili con carne or biscuits and gravy? New England clam chowder or sausage and strudel? And what, precisely, made an atmosphere "homey"? Lace curtains and plush carpets? Pictures on the mantle and candles on the table? As they began to implement the new campaign, restaurateurs wrangled with sticky linguistic and theoretical issues. How would they duplicate "Home Sweet Home" if every patron's home was different? If the essence of home was its individuality and intimacy, how could it be packaged and sold? As they attempted, awkwardly, to define "home" - and more difficult yet, to reproduce and market it-restaurateurs found themselves mired in formidable contradictions.

"Home cooking," they eventually concluded, was the antithesis of modern cooking. In an era of prepackaged foods, name brands, and nationwide chains, it was humble, seasonal, and local - "the scrapple of Pennsylvania, the genuine clam chowder of New England, the sweet potato pone of Maryland, for a slice of which General Lee would walk a mile." ${ }^{34}$ In a decade of increasing calorie-consciousness, it was hearty, creamy, and rich: cornmeal mush, fried eggs, codfish cakes, and "ham, boiled or fried but of the best flavor and half an inch thick, at least." 35 Home cooking adhered to regional tradition and rejected the artificial flavors and condiments promoted by food producers and manufacturers. It was "food cooked slowly so as to bring out the natural flavors instead of hiding them under neutralizing sauces and foreign flavors." 36 "The only 'a la' to our steaks," boasted one participating restaurant, "is a la salt, pepper, and butter." 37 Perhaps most important, in an age of mass production, home cooking was handcrafted and personal. Unlike canned, processed, factory-made food, it bore "distinctive flavors" that revealed the pride, "individuality," and "loving care" of its skilled and meticulous creators. ${ }^{38}$

"Home atmosphere," too, bore few, if any, marks of modernity. With refined, often antique, furniture and decor reminiscent of Victorian parlors and Colonial kitchens, "home atmosphere" restaurants bucked modern streamlined and art-deco design trends: "Golden dragons and purple poppies," warned one restaurateur, "do not belong in the wall decorations." These restaurants were to provide a cheerful, cozy, and restful sanctuary to city dwellers exhausted by the hectic routines of modern life. In Dayton's Grey Manor Restaurant, housed in an imposing white antebellum manor, "you immediately feel at home," boasted the owner. No longer just faces in an urban crowd, patrons of "home" restaurants became members of a "big family" - secretaries broke bread with lawyers, proprietors greeted customers by name, and strangers became friends. ${ }^{39}$ At one Portland, Oregon, cafeteria, noted for its exceptionally "homelike" atmosphere, “waitresses remember [patrons'] particular wants; whether their tea shall be green or black, whether they shall have French or mayonnaise dressing on their 


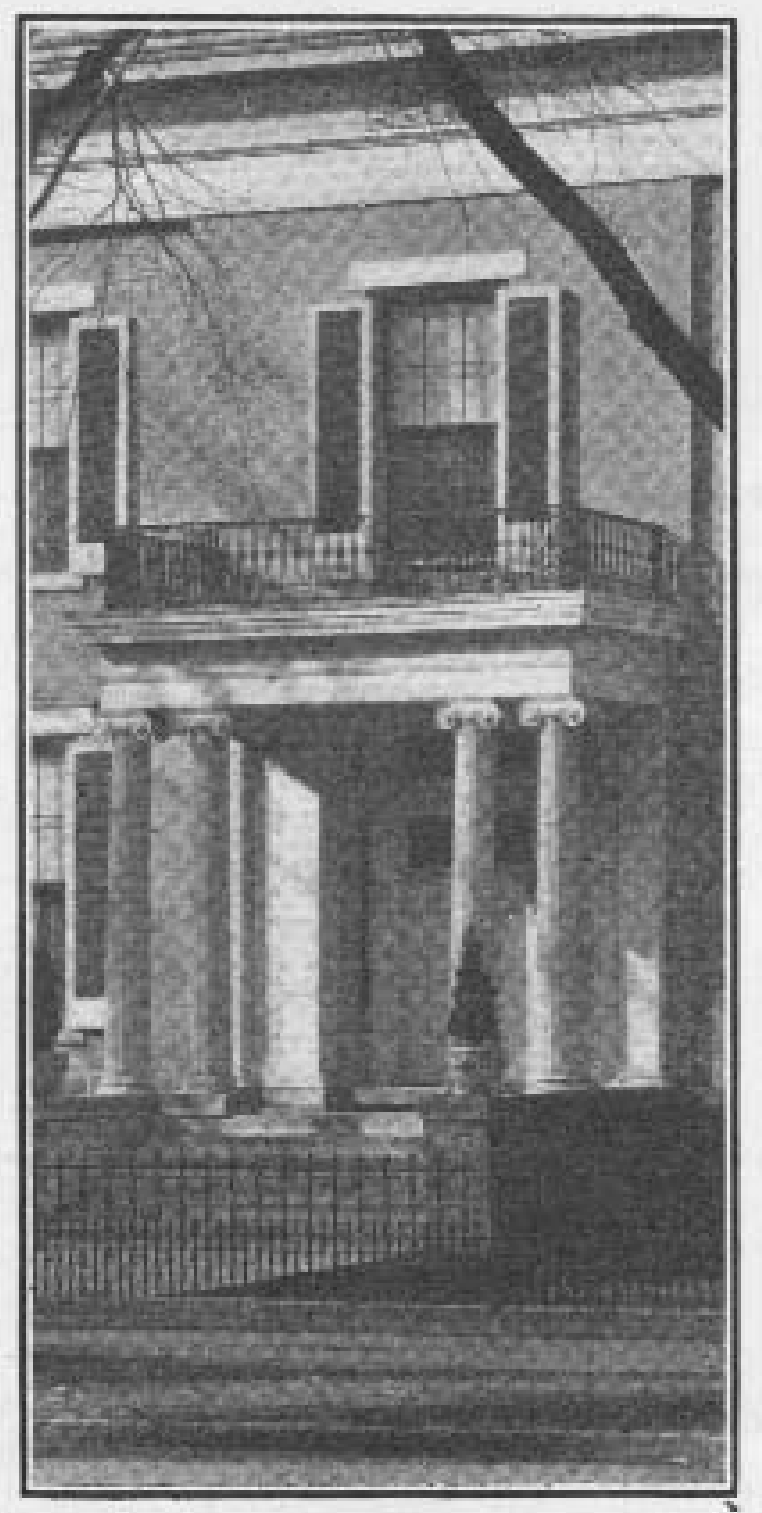

Grey Manor was formerly a private mansion. Its entrance is in excellent harmony with the home-like atmosphere that makea this restaurant so popular.

Grey Manor, Dayton, Ohio. From The American Restaurant, March 1926, p.45.

combination salad." Like "home cooking," "home atmosphere" became a code word for the customized service that was fast disappearing in an age of mass production. To feel at home, suggested industry leaders, was to feel the increasingly elusive "personal touch."

\section{Visions of Mother}

But what truly made the "home" restaurant "homelike," claimed restaurateurs, was less what was served and where it was served, than who served it. At the core of "home cooking" and "home atmosphere" was cheerful and diligent female service. "Deep down in every man's heart is a desire to have food handed to him by a woman," reported a trade journal in 1928. "A woman with a 'homey smile' does more to make a man feel at home in a strange eating place than anything." "Mature types," they suggested, were "superior to flappers," as they conjured up nostalgic "visions of Mother." National Restaurant News reported that one cafeteria in an East Coast city even hired a "dear old lady of 65 years" to speak with guests in the restaurant. "With snow white hair, parted in the middle, a nice, clean calico dress that just touched the floor, and a snow-white muslin apron starched stiff...she was a real mother, complete to the last detail, even to the old fashioned band ring on her finger." Not only did she successfully sell the daily lunch special, Ye Old Tyme Vegetable Soup with Dumplings, she attracted many new customers entranced by the possibility of getting "a look at "mother."'+2

Far more dignified than the male "hash slingers" of disreputable "greasy spoons," women cooks lent a veneer of gentility and domesticity to the restaurant. According to one restaurateur, they furnished a powerful psychological effect that caused customers to think uncontrollably of their mothers, and, in the process, to open their wallets. Schrafft's restaurant chain publicized its use of "women cooks only," while one chain of Kansas City cafeterias promoted its breads, dinners, and desserts as entirely "woman made." 43 "I want everyone to know that there is one place in Kansas City where you can get good old-fashioned strawberry shortcake," announced proprietor Myron Green in a local newspaper advertisement. "I serve it this way because it's better, and as my cooks are all women right out of Kansas City homes, they don't know how to make it any other way." Readers could use a coupon at the bottom of the advertisement for "one full order of woman-made strawberry shortcake," free with the purchase of any lunch or dinner fifteen cents or more. ${ }^{44}$

Sentimental and highly contrived, the "home cooking" campaign of the 1920 s tried to ease public fears about culinary standardization and commercialization - and perhaps most important, about the changing status of womenby generating nostalgia for an idealized premodern past. Bathed in soft lighting from antique fixtures, soothed by the aroma of freshly baked bread and by warm personal greetings from grey-haired "Mothers," patrons would forget the stresses and strains of modernity, and of women's rapidly changing social and domestic roles, all for a modest price. 
The ironies implicit in this commercial utopia were many. Hardly an antidote to canned and processed goods, the "home cooking" of most restaurants depended heavily, if not entirely, on mass-manufactured products. Advertisements for Campbell's soup, Borden's cheese, Wesson oil, and JellO filled the pages of restaurant industry journals, while featured "home style" recipes from Fleischmann's Yeast and Kellogg's shamelessly promoted the manufacturers' flours, seasonings, and cereals. The "distinctive flavors" that much home cooking promised were achieved through standardized recipes; the "personal touch" meant that dishes were prepared at least partially by human hands, rather than entirely by mixers, ovens, steamers, and other large-scale restaurant equipment. Though "home service" was supposed to be neither rushed nor loud, many cafeterias and lunchrooms advertised as "homelike" in fact bustled with noisy crowds. Far from leisurely or relaxed, they attracted patrons on the basis of their prompt, efficient service. "The beauty of it all is that in our quick service cafeterias we serve you quicker than other places generally can," boasted the Myron Green cafeterias. ${ }^{45}$ Perhaps most ironically, "home cooking" restaurants depended on the paid labor of married women, a practice antithetical to their domestic vision. Though few restaurateurs would admit it, the home cooking restaurants wholly supported both the institutions and the commercial products they so fervently denounced.

When pressed, restaurateurs tried to finesse the contradictions. Ideally, "home cooking" was individual and personal, with the "self-expression" of the housewife or cook varying according to her taste or mood. But restaurants depended on consistency. So the industry held to a different standard of individuality: the best restaurant was the rare establishment that served consistent and predictable meals. In the old days, wrote restaurant consultant Linda Brown, mothers had little need for cookbooks and recipe cards. Guided by skill and "constant practice," their cooking rested on tradition and memory. But because modern women lacked culinary training and had little practice preparing meals at home, female restaurant cooks needed precise, standardized recipes to reach the "point of perfection" that their mothers had achieved naturally. In a vision she shared with many others, Brown promised that modern "science" would restore the traditional "home cooking" it had done so much to destroy. ${ }^{46}$

In spite of its evident ironies and contradictions, the "home cooking" campaign of the 1920 proved extraordinarily popular and, ultimately, successful. Restaurateurs spent millions on "home style" menus, cuisine, and decor; those without funds for large-scale renovations purchased signs and banners promising "real home service," "old-fashioned cooking," and "foods prepared in a genuine home way." The Park Lunch Restaurant in Plainfield, New Jersey, promoted itself as the "Home of Cooking that Makes Mothers Jealous"; the Maryland Lunch in Baltimore, "The Home Like Place to Eat"; and Ye Yum Yum Shop in Pasadena, the place "Where Home Cooking is King." ${ }^{47}$ Other restaurants invested in new furniture, lighting, and window displays. One elaborate cafeteria window display, described in National Restaurant News, featured "a small cook stove, Mother dressed in an old-time white apron, and two children playing." To create the effect of a roaring fire, red tissue paper, illuminated by electric lights, shone brilliantly in the stove. Though costly and time-consuming, these creative efforts paid off: "by putting some visual evidence of the home" in the cafeteria, the owner overcame a "slump in patronage" and reaped tremendous financial rewards. ${ }^{48}$

The cafeteria owner with his inventive window display was hardly the only restaurateur who profited during the 1920s. National Restaurant News reported proudly that throughout the nation, restaurateurs enjoyed fantastic success. Between 1915 and 1930, the percentage of daily meals consumed in restaurants increased from three to fifteen; in some cities, restaurants served twenty-five to thirty-five percent of all meals. ${ }^{49}$ According to the New York Times, in 1929 nearly one-sixth of all food eaten in the United States appeared on plates and trays in cafeterias, lunchrooms, coffee shops, and cafés. No longer a rare diversion or occasional necessity, dining out had become a fullfledged "national habit." With an "army of daily restaurant patrons" spending millions of dollars a day at the nation's more than 120,000 eating establishments, Americans, the Times claimed, had become "the greatest patrons of restaurants in the world." 50

The increase in restaurant dining sprang from several complex developments, including continued urbanization, popularization of the automobile, and greater numbers of women working outside the home. Nevertheless, the "home cooking" campaign also contributed vastly to the new popularity of restaurants. Many of the customers were middle-class Americans from "real homes," noted the New York Telegram. Impressed by the creative nostalgia of "home cooking" and its associations with traditional domesticity, as well as by improvements in food quality and sanitation, "respectable" men and women forgot the "greasy spoon" image and flocked to restaurants. Once considered "beneath consideration, socially," restaurants, claimed National Restaurant News, in large part because of "home cooking," had at last achieved a much-deserved measure of dignity. ${ }^{51}$

Perhaps even more than the middle-class husbands and 
businessmen toward whom the "home cooking" campaign had been primarily directed, women were attracted to this new type of eating establishment. Though fewer than twenty percent of restaurant customers in 1910 were female, by 1926 women constituted more than sixty percent of the clientele. ${ }^{52}$ Drawn by healthy, traditional foods, neatly attired female workers, and clean, "home like" furnishings, women, at least initially, felt safe in the "home atmosphere" restaurants.

\section{The Decline of "Home Cooking"}

Despite its initial popularity, the vogue for "home cooking" eventually declined. By the early 1930s, patrons were growing tired, if not downright skeptical, of the "old fashioned" slogans and motifs. Customers who had once been lured by the promise of home-cooked foods discovered that "the food they are eating at these restaurants is not, after all, home cooked. Then they are angry at the restaurants and return to their old resolution not to eat in a public place unless they absolutely must." 53 Even female interest in "home cooking" soon began to decline. Weary housewives and mothers sought an escape from home; they didn't want to be reminded of it. Bored with grey-haired Mothers, overstuffed couches, and home-baked pies, the new female restaurant patrons yearned for more effective and inventive solutions to their domestic woes.

As for the "home cooking" slogan, "[i]t is seen on the windows of Chinese, Greek, Russian, Italian, French, Hungarian restaurants - it means nothing!" complained proprietor Helen Ewing in 1931. "Its virtue has been completely destroyed. It is like over-emphasis which announces a lie." 54 Many restaurants gradually abandoned the "home cooking" theme, replacing the antique tables and lace curtains with more modern décor. However, restaurants did not give up on their efforts to capitalize on middle-class domestic anxieties. For years, the restaurant industry would continue to lure patrons with promises of family harmony, female subservience, and the feasibility of domestic bliss.

Sensing the change in clientele and climate, in the early 1930 industry leaders announced the start of a new publicity drive, a "large-scale cooperative advertising movement" to be carried out in newspapers, movie theaters, shop windows, and even over the airwaves. Like "home cooking," the "Take Her Out to Dinner at Least Once a Week" campaign promised middle-class patrons domestic utopia. Unlike "home cooking," however, which had sought to revive domesticity through a retreat to the past, the new campaign attempted to revitalize middle-class homes by actively restructuring family relationships. "No matter what the weather actually is, it's always fair weather when you take the family out to dinner," promised a 1931 advertisement. "Hot weather, family squalls, and gloomy days all disappear before the anticipated pleasure of eating dinner at a restaurant." 55

Portrayed by the restaurant industry as the solution to "troublesome kiddies," family fights, and even troubled marriages, restaurant dining held the key to domestic harmony. To weary wives, the new campaign promised relief from nightly "kitchen slavery" and, in some cases, nothing less than complete "emancipation." "It is our thought," wrote noted newspaper columnist Damon Runyon, who was paid to endorse the campaign, "that every new restaurant...is another step towards the final emancipation of the American woman from that bondage known as cooking for the family." 56 For husbands fearful of such revolutionary possibilities, promoters ran advertisements assuring men that restaurant dining led not to liberation, but to greater female docility. "The reason most marriages fail," announced National Restaurant Association leader Ray Fling, "is because the time the wife formerly spent in making herself look pretty is taken up in backbreaking work which has the effect of making her homely. Romance fades in proportion as the wife's hands roughen from hot, soapy water, as her complexion coarsens from standing over a stove, and as her temper gets out of control." Wives remained happy, pretty, and compliant, he assured, if taken out to restaurants on a regular basis. ${ }^{57}$ "The wise husband of today gives his wife frequent outings so as to avert the danger of her going on strike. TAKE HER OUT TO DINNER AT LEAST ONCE A WEEK." 58

The campaign succeeded: "Hundreds of families...are now dining out regularly as a result of the campaign," reported The American Restaurant in $1932 .{ }^{59}$ This lucrative approach to restaurant advertising continued throughout the century, with the restaurant industry claiming that the simple act of dining out facilitated domestic cohesion, rather than impeded it. As historian Andrew Hurley has written, working-class proprietors of 1950 os diners skillfully used this approach to lure a "respectable" family clientele. "Wives who cook and do dishes should be granted these three wishes: a graceful mate, a well-kissed cheek, and a restaurant dinner every week," read the place mats at one East Coast diner. Eating out promised "evenings free and uncluttered with cooking chores and dirty dishes," enabling families to spend more satisfying time together. A popular advertising campaign in the 1950 s, designed and promoted by the National Restaurant Association, urged families to "Enjoy Life-Eat Out More Often." Ads juxtaposed the slogan against images of happy families seated together in diner booths. Following in the footsteps of the "home 
cooking" restaurateurs of the 1920s, the owners of diners, lunchrooms, roadside restaurants, and other inexpensive eating establishments found that the most effective means to profit lay in appeals to family and home. ${ }^{60}$

"Home cooking" has persisted to this day as a popular theme for restaurant cuisine and decor, although perhaps with less fervor than in its 1920s heyday. In one of the great ironies of the modern social experience, restaurants have lured middle-class Americans by promising to restore the very traditions they helped to destroy. Beginning in the 1930s, famed restaurateur Howard Johnson built a roadside empire of orange-roofed, Colonial-style "home cooking" restaurants that remained popular for over half a century. The Denny's coffee-shop franchise currently markets a line of "Mother Butler" pies, and the Wendy's fast-food chain features "old fashioned" hamburgers in a kitschy atmosphere with faux stained-glass lamps, wooden chairs, and tables imprinted with images from Victorian-era newspapers. Other well-known chains, such as Marie Callender's and Friendly's Ice Cream, invoke similar motifs. Despite the recent passion for ethnic foods, nouvelle cuisine, and ever more fanciful theme restaurants, there persists within the middle-class American psyche a longing for an idealized home. ๑

NOTES

1. Frederick goes on to say: "The bride has lost her grip on the egg-beater and biscuit cutter. We can not deny that old-fashioned 'home cooking' is passing, and that woman has to a great degree already yielded the palm as a cook to the restaurant and hotel chef." Christine Frederick, "Vamping' Hubby from His Home," Cafeteria Management, December 1927: 11.

2. “'Home-Cooking' Made This Man Famous," The American Restaurant Magazine, December 1926: 8o.

3. Robert and Helen Lynd, Middletown (New York: Harcourt, Brace, 1926), 154-6.

4. Mary Wilson, "Public Food Service Demands Application of Science," Cafeteria Management, November 1926: 18.

5. William Johnson, "What Has Happened to Home?" Collier's, 16 August 1924: 8.

6. Helen Ewing, "What About this 'Home Cooking," The American Restaurant Magazine, March 1931: 45.

7. Susan Strasser, Never Done: A History of American Housework (New York:

Pantheon, 1982), 23 .

8. "Your Obedient Servant," Sunset, January 1926: 76. In the 189os, newspapers and magazines reported a "servant crisis" among the middle class, as domestic servants left their employers to pursue the growing number of factory, clerical, and retail jobs available in major cities. See Harvey Levenstein, Revolution at the Table: The Transformation of the American Diet (New York: Oxford University Press, 1988), ch.5.

9. Charlotte Perkins Gilman, The Home: Its Work and Influence (1903, reprint Chicago: University of Illinois Press, 1972), 136.

10. Laura Shapiro, Perfection Salad (New York: Farrar, Straus and Giroux, 1986), 190.

11. Lynd, Middletown, 154 .

12. Jennifer Scanlon, Inarticulate Longings (New York: Routledge, 1998), 73.
13. "Summer Meals in Electric Ranges," Good Housekeeping, July 1925: 72.

14. Sinclair Lewis, Babbitt (New York: Harcourt, Brace, 1922), 146, 75.

15. Sylvia Lovegren, Fashionable Food (New York: Macmillan, 1995), ch.1.

16. "Come Out of the Kitchen," Collier's, 20 November 1926: 18.

17. U.S. Bureau of Home Economics statistics cited in Joann Vanek, "Time Spent in Housework," Scientific American, November 1974: 118-19.

18. Caroline B. King, “Quick-Cooked Meats for Hurry-Up Dinners,” The Ladies' Home Journal, May 1926: 45

19. Scanlon, Inarticulate Longings, 80, 107.

20. “'Breaking Up Homes,” Restaurant Management, October 1926: 47.

21. "Home-Cooking' Made This Man Famous."

22. Mary A. Wilson, "Dishes That Bring Visions of Mother," National Restaurant News, November 1924: 7 .

23. T.T. Frankenburg, "National Convention Program Memorable One," National Restaurant News, July 1924: 22.

24. H.C. Siekman, "The Parade of Restaurant Progress," The American Restaurant Magazine, October 1939: 39.

25. "Chicago Restaurant Methods and Development," National Restaurant News, August 1923: 26.

26. Lillian Cassels, "Efficient Lighting," National Restaurant News, May 1923: 18.

27. J.W. Wiley, "Combining Art and Sanitation," National Restaurant News, July 1923: 32 .

28. Clifford E. Clinton, "I'll Say", Cafeteria Management, October 1926.

29.“The New Mecca Lunchroom,” National Restaurant News, January 1923: 16.

30. “Home-Cooking' Made This Man Famous."

31. Clarence M. Lindsay, "Doing It Better Than Mother Did-at Boos',

National Restaurant Magazine, March 1925: 13.

32. Wilson, "Dishes That Bring Visions of Mother."

33. L.D. Roueche, "Singling Out the Class Best to Cater To," Restaurant News and Management, December 1925: 7 .

34. Frederick, “Vamping' Hubby from His Home.”

35. Ewing, "What About this 'Home Cooking."

36. Robert S. Merrell, "How they Are Urged to Dine Out," National Restaurant News, November 1923: 38 .

37. Warren P. Staniford, "How Merchandising American Cookery Increased Our Volume Despite the Depression," Restaurant Management, June 1931: 364.

38. "News of the Cafeteria Field," Cafeteria Management, December 1926: 22.

39. Mary C. Budroe, "How We Secure True Home Atmosphere in Our Restaurant," Restaurant News and Management, March 1926: 27.

40. Florence Marquis Hunt, "They Do Not Pass Our Door," Cafeteria Management, June 1928: 15. During the 1920s, "tea rooms"-small roadside cafés, often run by women, serving light lunches, snacks, and desserts-became nationally popular for their nostalgic Colonial and Victorian decor. See Jan Whitaker, "Catering to Romantic Hunger: Roadside Tea Rooms, 1909-1930", Journal of American Culture 15 (Winter 1992): 17-24.

41. "The Woman Behind the Counter," Cafeteria Management, November 1928: 13 .

42. “'Mother' Was There in Person to Greet Patrons," National Restaurant News, January 1925: 18 .

43. Mabel Anderson, “The Three R's of Food Preparation," National Restaurant News, April 1927: 123.

44. Advertisement for Myron Green Cafeterias, National Restaurant News, May 1925: 9.

45. Ibid. 